\title{
Originals
}

\section{Skeletal muscle glucose transporter gene expression is not affected by injecting growth-hormone-secreting cells in young rats}

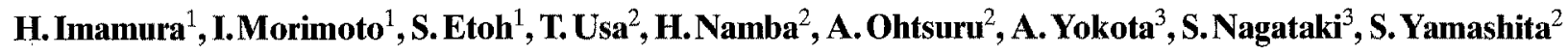 \\ ${ }^{1}$ The First Department of Internal Medicine, University of Occupational and Environmental Health, Kitakyushu, Japan \\ ${ }^{2}$ Department of Cell Physiology, A tomic Disease Institute, Nagasaki University School of Medicine, Nagasaki, Japan \\ ${ }^{3}$ The First Department of Internal Medicine, Nagasaki University School of Medicine, Nagasaki, Japan
}

Summary. To elucidate the diabetogenic effect of growth hormone on glucose metabolism the regulation of glucose transporter (GLUT) gene expression was examined in rat skeletal muscles. Female Wistar-Furth rats were implanted subcutaneously with growth-hormone-producing pituitary tumour $\left(\mathrm{GH}_{3}\right)$ cells. Animals were killed 4 or 9 weeks after $\mathrm{GH}_{3}$ cell injection. Although body weight, serum growth hormone and insulin-like growth factor I levels were remarkably elevated during the 4-9 week period, serum blood glucose levels were within normal range. Muscles were obtained from the quadriceps muscle, diaphragm and heart, respectively. Northern blot analysis and Western blot analysis were performed using specific cDNA probes and antibodies. During the $4-9$ week period, the levels of muscle GLUT 1 and 4 mRNA (corrected by $\beta$-actin mRNA level) in each muscle from the rats injected with tumour cells were not significantly different from those of control rats. Chronic elevation of growth hormone in these rats did not cause any change in GLUT 1 and 4 expression compared to the controls during the euglycaemic period. These results provide the first evidence that chronic growth hormone elevation itself does not affect a key gene of in vivo glucose metabolism.

Key words: GLUT 1, GLUT 4, growth hormone, muscle, in vivo, mRNA.
Acromegaly is the clinical syndrome caused by excessive secretion of growth hormone (GH) from a functioning pituitary tumour [1]. One metabolic aspect of this syndrome is insulin resistance induced by $\mathrm{GH}$, the mechanism of which is still unknown [2]. Clinically acromegalic patients may have glucose tolerance ranging from normal carbohydrate metabolism to diabetes mellitus of varying severity [3-6]. There is, however, considerable confusion about the detailed aspects of $\mathrm{GH}$ action on carbohydrate metabolism, in part due to two different actions of $\mathrm{GH}$; insulin-like and anti-insulin biological effects [7]. In experimental animals, acute injection of an excess amount of GH induced an insulin-like effect and chronic effects of $\mathrm{GH}$ are stimulation of insulin secretion and induction of insulin resistance [8-12]. In addition to these effects, an important role of $\mathrm{GH}$ is to regulate glucose production by the liver, glucose uptake in peripheral tissue (i. e., muscle and fat) and systemic amino acid turnover [2]. Studies of insulin receptor on circulating blood cells from patients with acromegaly [13] or on tissues from animals bearing GH-secreting tumours [14] provide insight into some of the mechanisms of insulin resistance in states of GH ex- cess. The functional role of insulin receptor changes in the insulin resistance of acromegaly is, however, still unknown. Evidence that insulin resistance is secondary to post-receptor defects has been recently reported [15]. Another important function of insulin is its control of blood glucose concentrations by the stimulation of glucose uptake in specific insulin-sensitive tissues. Skeletal muscle makes up the largest tissue mass in the body and plays an important role in glucose homeostasis. Glucose transport is the first and probably rate-limiting step of muscle glucose utilization [16] and the muscle glucose transporter (GLUT) has been identified as a potential site for the development of insulin resistance [17]. Although the different types of GLUT have been cloned and characterized as membrane-spanning proteins [18-25], studies of in vivo GH action on GLUT expression must be performed which will further our understanding of the mechanism of insulin resistance by chronic $\mathrm{GH}$ excess. Therefore, to elucidate the diabetogenic action of GH on muscle GLUT, we have examined the in vivo regulation of GLUT 1 and 4 during euglycaemia in various muscles: quadriceps muscle, diaphragm and heart. 
Table 1. Changes of body weight, blood glucose and hormone levels in experimental rats

\begin{tabular}{|c|c|c|c|c|c|c|}
\hline & \multicolumn{3}{|l|}{ Control rats } & \multicolumn{3}{|c|}{$\mathrm{GH}_{3}$ tumour bearing rats } \\
\hline & 4 Weeks & 6 Weeks & 9 Weeks & 4 Weeks & 6 Weeks & 9 Weeks \\
\hline Body weight (g) & $167 \pm 10$ & $171 \pm 12$ & $196 \pm 3$ & $179 \pm 18$ & $241 \pm 21^{a}$ & $341 \pm 33^{b}$ \\
\hline $\begin{array}{l}\text { Blood glucose } \\
(\mathrm{mmol} / 1)\end{array}$ & $5.5 \pm 0.83$ & $8.28 \pm 1.00$ & $9.44 \pm 0.11$ & $6.22 \pm 0.67$ & $8.22 \pm 0.89$ & $9.83 \pm 0.11$ \\
\hline $\begin{array}{l}\text { Growth hormone } \\
(\mathrm{nmol} / \mathrm{l})\end{array}$ & $9.55 \pm 6.82$ & $7.27 \pm 3.18$ & $4.64 \pm 4.36$ & $22.27 \pm 8.64^{\mathrm{a}}$ & $188.64 \pm 36.18^{\mathrm{b}}$ & $287.32 \pm 176.23^{b}$ \\
\hline $\begin{array}{l}\text { Insulin-like growth } \\
\text { factor I (nmol/I) }\end{array}$ & $20 \pm 8.53$ & - & - & $26.93 \pm 3.73^{\mathrm{a}}$ & $34.67 \pm 8.40^{\mathrm{b}}$ & $41.26 \pm 13.20^{b}$ \\
\hline $\begin{array}{l}\text { Insulin } \\
\text { (mU/1) }\end{array}$ & $22.16 \pm 1.97$ & - & - & $46.51 \pm 7.15^{a}$ & $51.17 \pm 11.34^{a}$ & $48.99 \pm 13,65^{\mathrm{a}}$ \\
\hline
\end{tabular}

${ }^{\mathrm{a}} p<0.01,{ }^{\mathrm{b}} p<0.001$ vs respective control rats. $n=3-15$, mean $\pm \mathrm{SD}$

\section{Materials and methods}

\section{Animals and experimental procedures}

Female Wistar-Furth rats were used for the experiments. The rats were maintained in the Laboratory Animal Center for Biomedical Research, Nagasaki University School of Medicine and housed in isolation in an environment of controlled light/darkness (lights on, $07.00-20.00$ hours) and temperature $\left(22 \pm 1{ }^{\circ} \mathrm{C}\right)$ and permitted free access to food and water [26]. At the age of 4 weeks $(100-120 \mathrm{~g})$, 22 rats were injected s. c. with $5.0 \times 10^{6} \mathrm{GH}_{3}$ pituitary tumour cells [27] suspended in $0.1 \mathrm{ml}$ Ham's F 10 medium containing penicillin $(100 \mathrm{U} / \mathrm{ml})$ and streptomycin $(100 \mu \mathrm{g} / \mathrm{ml})$ [28]. Twenty control rats were given an equal volume of vehicle Ham's $F 10$ only. Tumour-bearing and control rats were weighed each week, and tail yenous blood samples $(0.4 \mathrm{ml})$ were collected, centrifuged, and stored at $-20^{\circ} \mathrm{C}$. Glucose was measured in blood samples immediately. Four weeks after tumour cell injection, groups of rats (tumour-bearing and respective controls) werekilledby decapitation, quadriceps, diaphragm and heart were aseptically removed, quickly frozen, and stored at $-70^{\circ} \mathrm{Cuntilextraction} \mathrm{of} \mathrm{RNA} \mathrm{and} \mathrm{preparation} \mathrm{of} \mathrm{membrane.} \mathrm{Trunk}$ blood was collected from the heart simultaneously for hormone RIA.

\section{Radioimmunoassay}

Rat GH (rGH) and insulin-like growth factor I (IGF-I) serum concentrations were determined in duplicate at three dilutions by RIAs using materials supplied by the National Hormone and Pituitary Agency, NIADDK (Bethesda, Md., USA). In the IGF-I RIA recombinant IGF-I (Fujisawa Pharmaceutical Co,, Ltd., Osaka, Japan) was used as antigen and had a $50 \% \mathrm{~B} / \mathrm{B}_{0}$ (bound/background) to free ratio of $163 \mathrm{pg} /$ tube. Insulin was measured in duplicate by a solid phase RIA (Insulin Beas II, Dinabot, Tokyo, Japan). Circulating blood glucose levels were measured by Glucostor (Miles-Sankyo Co. Ltd., Tokyo, Japan).

\section{Northern gel analysis}

Muscle tissues taken from the animals were subjected to total RNA extraction by acid-guanidinium thiocyanate phenol-chloroform method [29]. Total cellular RNA $(25 \mu \mathrm{g})$ were denatured by incubation at $65^{\circ} \mathrm{C}$ with $50 \%$ formamide as described previously [30]. After RNA transfer from the gel to Hybond N nylon membrane paper, the paper was prehybridized and hybridized with $10^{6} \mathrm{cpm}\left[{ }^{32} \mathrm{P}\right]$-labelled GLUT cDNA probe, or $\beta$-actin cDNA before exposure to X-ray film for autoradiography as described previously [31]. The rehybridization was performed after incubating in $0.1 \times \mathrm{SSC}(1 \times \mathrm{SSC} ; 0.15 \mathrm{~mol} / \mathrm{l}$ $\mathrm{NaCl}$ and $0.015 \mathrm{~mol} / \mathrm{l}$ sodium citrate, $\mathrm{pH} 7.0$ ) and $0.1 \%$ sodium dodecylsulphate(SDS) at $95-100^{\circ} \mathrm{C}$ for $30 \mathrm{~min}$. The GLUT $1 \mathrm{cDNA}$ probe containing a 2.4 kilobase (kb) size DNA was provided by Dr. J. S. Flier (The Whitehead Institute of Biomedical Research, MIT, Boston, Mass., USA). The pGEM was used for propagation of pGT25L plasmid (Bam-HI cloning site) [32]. The GLUT 4 cDNA probe containing 800 basepair size cDNA and is a Hind III/EcoRI fragment of pGEM-3Zf (-) was provided by Dr. D. E. James (Washington University, St. Louis, Mo., USA) [33]. The $\beta$-actin probe was provided by Dr. L. Kedes (Stanford University, Palo Alto, Calif., USA) [34]. The probes used in this study were labelled with $\alpha-\left[{ }^{32} \mathrm{P}\right]$-dCTP by multiprime DNA-labelling systems (Amersham, Tokyo, Japan) to a specific activity of approximately $5-10 \times 10^{8} \mathrm{cpm} / \mu \mathrm{gDNA}$.

\section{Quantitation of GLUT 1 and 4 mRNA}

The specificity of GLUT 1 and 4 mRNA was confirmed by the positions of autoradiographic bands, $2.9 \mathrm{~kb}$ and $2.8 \mathrm{~kb}$, respectively. To compare the density of each band, a Bioimage Analyser (BAS-2000; Fuji Film, Tokyo, Japan) was used to accurately measure the density of GLUT and $\beta$-actin mRNA, respectively.

\section{Preparation of membranes}

Total membrane fractions from rat tissues were prepared as previously described with some modifications [35]. Muscles were excised and homogenized by a Polytron homogenizer (Kinematica, Littau, Switzerland) in $10 \mathrm{mmol} / \mathrm{l}$ Tris- $\mathrm{HCl}, 1 \mathrm{mmol} / \mathrm{EDTA}$, $250 \mathrm{mmol} / 1$ sucrose, $\mathrm{pH} 7.4$ containing $1 \mathrm{mmol} / 1$ phenylmethylsulphonyl fluoride. The homogenates were centrifuged at $900 \times \mathrm{g}$ for 10 min at $4^{\circ} \mathrm{C}$ to sediment the fraction containing mainly the nuclei and mitochondria. The resulting supernatant was centrifuged at $146 \times 10^{3} \mathrm{~g}$ for $75 \mathrm{~min}$ at $4^{\circ} \mathrm{C}$ to yield a pellet designated as the total membrane fraction in this study.

\section{Western blot analysis}

Membrane fractions ( $50 \mu \mathrm{g}$ protein) prepared as described above were suspended in $1 \%$ SDS and $2.5 \%$ mercaptoethanol, $12.5 \%$ glycerol and $50 \mathrm{mmol} / \mathrm{l}$ dithiothreitol in $10 \mathrm{mmol} / \mathrm{ITris}-\mathrm{HCl}$ ( $\mathrm{pH} 6.8$ ) and subjected to SDS-polyacrylamide (10\%) gel electrophoresis as described previously [36]. Electrophoretic transfer to nitrocellulose membrane (ADVANTEC, Tokyo, Japan) was carried out. The nitrocellulose filters were incubated for $1 \mathrm{~h}$ at room temperature in phosphate-buffered saline $(0.18 \mathrm{mmol} / 1 \mathrm{NaCl}, 2.68 \mathrm{mmol} / \mathrm{KCl}$, $4.02 \mathrm{mmol} / / \mathrm{Na}_{2} \mathrm{HPO}_{4}, 1.76 \mathrm{mmol} / \mathrm{KH}_{2} \mathrm{PO}_{4}$ ) (PBS), pH 7.5 containing $5 \%$ skim milk powder, followed by incubation with either a $1: 200$ dilution of the polyclonal rabbit anti-rat brain glucose transporter peptide antibody (Transformation Research Institute, Framming- 

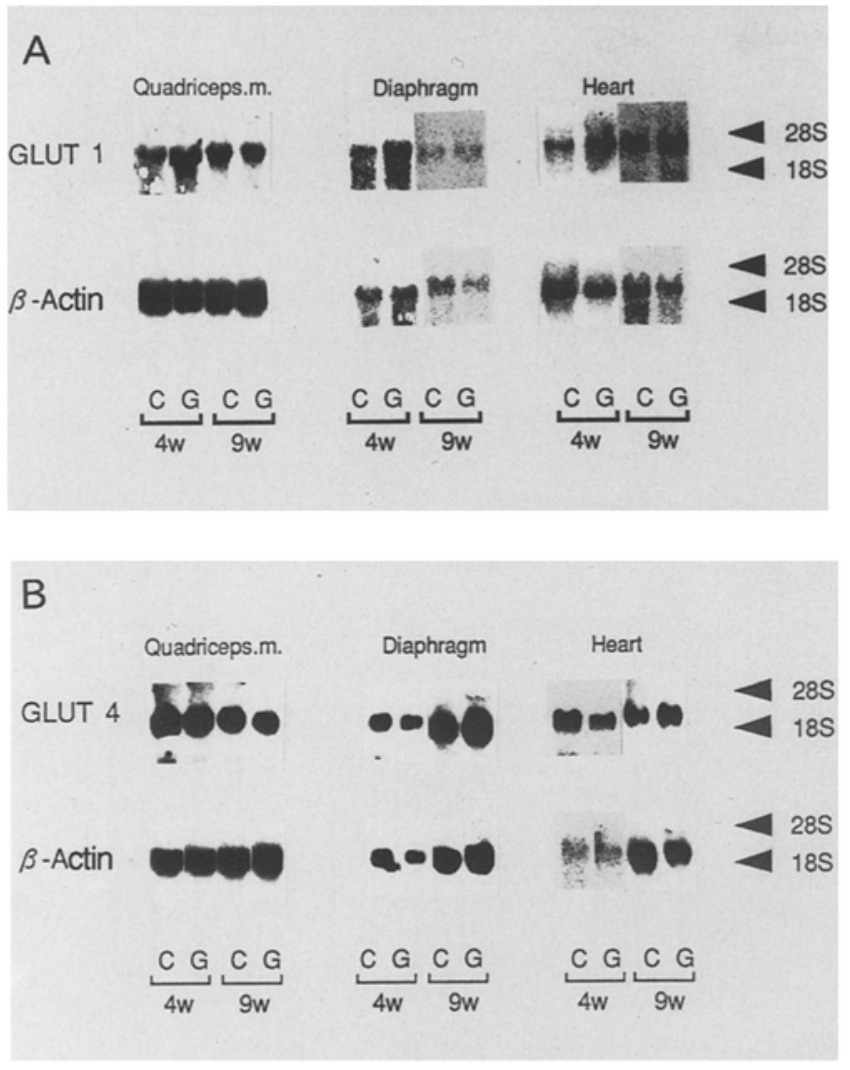

Fig.1A,B. Autoradioraphic analysis of GLUT mRNA expressions in each muscle obtained from quadriceps, diaphragm and heart, respectively. Total RNA was extracted from the rats bearing growth hormone producing tumours (G) and their respective controls (C), 4 and 9 weeks later. The details of Northem blot analysis are described in the Materials and methods. A: Upper panels show a single 2.9 kilobase (kb) GLUT 1 mRNA in each muscle 4 and 9 weeks after tumour injection. The same blot was reprobed with $\left.{ }^{32} \mathrm{P}\right] \beta$ action $\mathrm{CDNA}$ as seen in the lower panels; B:Upper panels showed a single $2.8 \mathrm{~kb} \beta$ action mRNA. A representative blot is depicted. The same tendency was detected in other 4.9 week experimental periods

ham, Mass., USA) or a 1:40 dilution of mouse anti-rat glucose transporter (insulin-regulated) monoclonal antibody (IF-8) (Genzyme Corp., Cambridge, Mass., USA), in the same solution with $1 \%$ Triton X-100 for $1 \mathrm{~h}$ at $37^{\circ} \mathrm{C}$. The filters were washed for $30 \mathrm{~min}$ three times in PBS with $1 \%$ Triton $\mathrm{X}-100$ at room temperature, and incubated with ${ }^{125} \mathrm{I}$-labelled protein $\mathrm{A}(0.2 \mu \mathrm{Ci} / \mathrm{ml})$ for $1 \mathrm{~h}$ at $37^{\circ} \mathrm{C}$. The papers were washed two times in PBS with $1 \%$ Triton X-100 and autoradiographed for $1-4$ days. These papers were analysed by Bioimage Analyser.

\section{Statistical analysis}

All data are presented as the mean \pm SD. Statistical analysis was performed by the non-parametric tests (unpaired $t$-test, Wilcoxon). $P$ values less than 0.01 were considered to indicate a statistically significant difference.

\section{Results}

Four weeks after suspended tumour cells were injected, the tumour-bearing rats began increasing in body weight compared to controls. By the end of 9 weeks, the tumour-
A
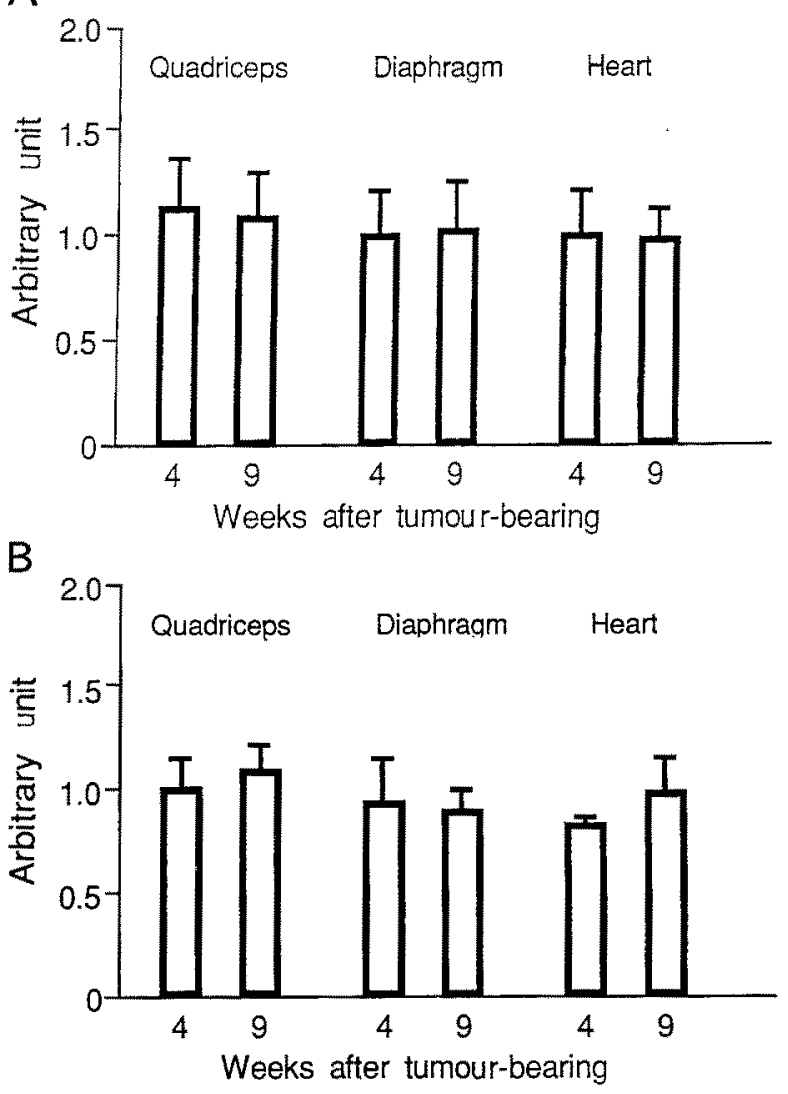

Fig.2 A,B. Quantitative analysis by Bioimage Analyser of GLUT mRNA levels after 4 and 9 weeks. The same amount of total RNA ( $25 \mu \mathrm{g} /$ lane) was loaded and the GLUT-1 or $4 \mathrm{mRNA} / \beta$-actin mRNA in each muscle was compared as an arbitrary unit $\left[\mathrm{GH}_{3}(\mathrm{GLUT}\right.$ mRNA $\beta$ actin mRNA)]/[Control (GLUT mRNA/ $\beta$-actin mRNA)]. A: GLUT 1 mRNA levels in each muscle after 4 and 9 weeks, $n=3-10$; B: GLUT 4 mRNA levels in each muscle after 4 and 9 weeks, $n=3-8$. There were no significant differences between the two time points for GLUT expression in the muscles studied

bearing rats were almost two times the weight of controls (341 $\pm 33 \mathrm{~g}$ vs $196 \pm 3 \mathrm{~g} ; p<0.001$ ). Circulating $\mathrm{GH}$ and IGF-I levels were elevated in tumour-bearing rats as shown in Table 1. During the 4-9 week period, however, the serum levels of glucose were not different between the two groups, although already 4 weeks after tumour implantation circulating insulin levels were elevated in $\mathrm{GH}_{3}$ tumour bearing rats $(48.99 \pm 13.65$ vs $22.16 \pm 1.97$, $p<0.01$ ). The RNA of tumour-bearing and respective controls was analysed by the Northern blot technique under stringent hybridization conditions with ${ }^{32} \mathrm{P}$ GLUT 1 and 4 cDNA probes, respectively. The cDNA recognized a single $2.9 \mathrm{~kb}$ GLUT $1 \mathrm{mRNA}$ and a $2.8 \mathrm{~kb}$ GLUT 4 mRNA, respectively in each muscle (Fig. 1). When Northern blots were loaded with equivalent amounts of total RNA lane $(25 \mu \mathrm{g})$, the abundance of the specific GLUT mRNA showed a 1.2- to 2-fold variation during the time period for each individual rat, with no significant difference in the mean between tumour-bearing and respective controls during the observation period. The same results were obtained from the three different muscles; quadriceps, diaphragm and heart. To better 

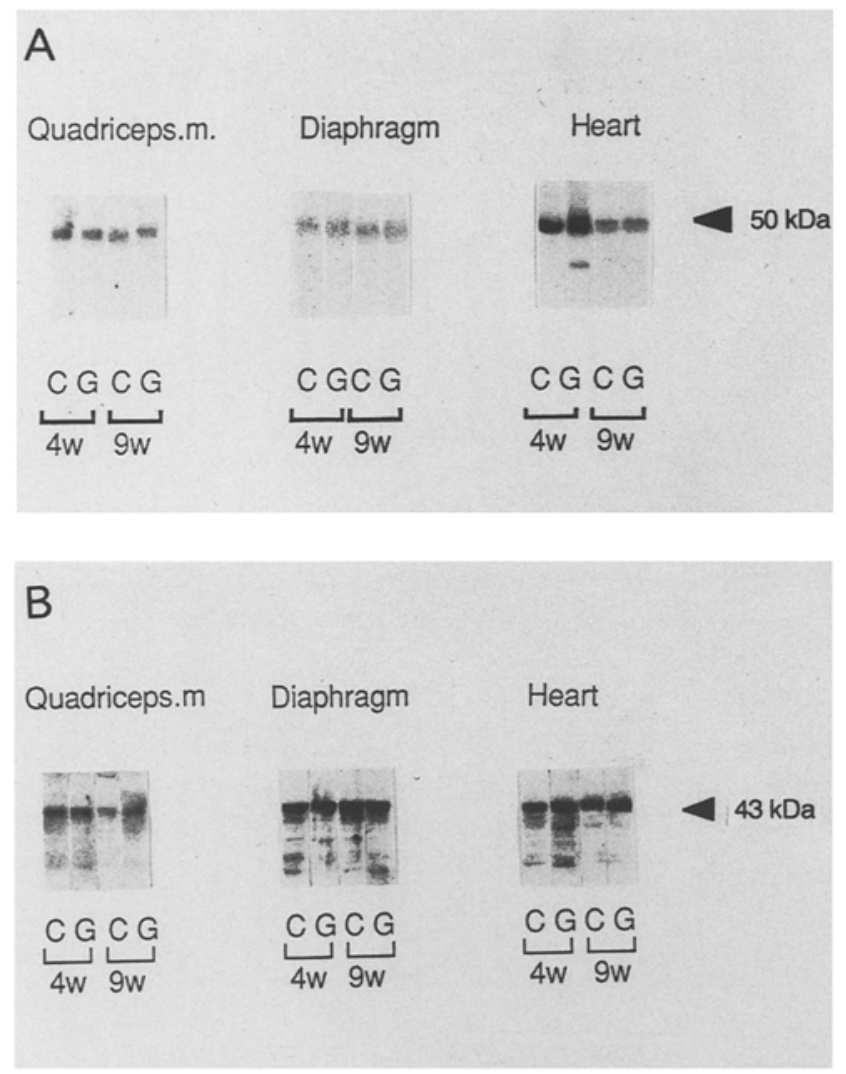

Fig. 3A,B. Western blot analysis of GLUT proteins obtained from quadriceps, diaphragm and heart muscle from rats bearing growth hormone producing tumours $(G)$ and control rats (C). A: a single band of $50 \mathrm{kDa}$ in all muscles studied was detected by polyclonal antibody against GLUT 1; B: GLUT 4 protein ( $43 \mathrm{kDa}$ ) was also detected by the monoclonal anti-GLUT-4 antibody (IF8)

quantitate the GLUT 1 and 4 mRNA levels, we also analysed three to ten rats at each time point using the quantitative bioimage analysing system. The GLUT 1 or 4 mRNA $/ \beta$-actin mRNA in each muscle obtained from tumour-bearing rats at the indicated time point was compared with those from respective controls. The abundance of GLUT 1 and 4 mRNA at each muscle was not altered during the 4-9 week period (Fig. 2).

The amount of GLUT 1 and 4 protein in a crude membrane preparation of each skeletal muscle was quantitated by Western blotting with two independent specific antibodies against rat GLUT 1 and 4, respectively. The polyclonal antibody against GLUT 1 could detect a single band of $50 \mathrm{kDa}$ in quadriceps, diaphragm and heart muscle, respectively. The relative abundance of GLUT 1 protein in tumour-bearing rat was compared with that in respective controls after 4 and 9 weeks of treatment. There was no change observed between them (Fig. 3A). The immunoblots were also performed with an antiGLUT 4 antibody (1F8). The size and amount of GLUT 4 protein in tumour-bearing rats did not change compared to that of the respective controls after 4-9 weeks of treatment (Fig.3B). To further confirm the stability of GLUT 1 and 4 protein levels, the three different muscles were subjected to Western blot analysis using tumour-
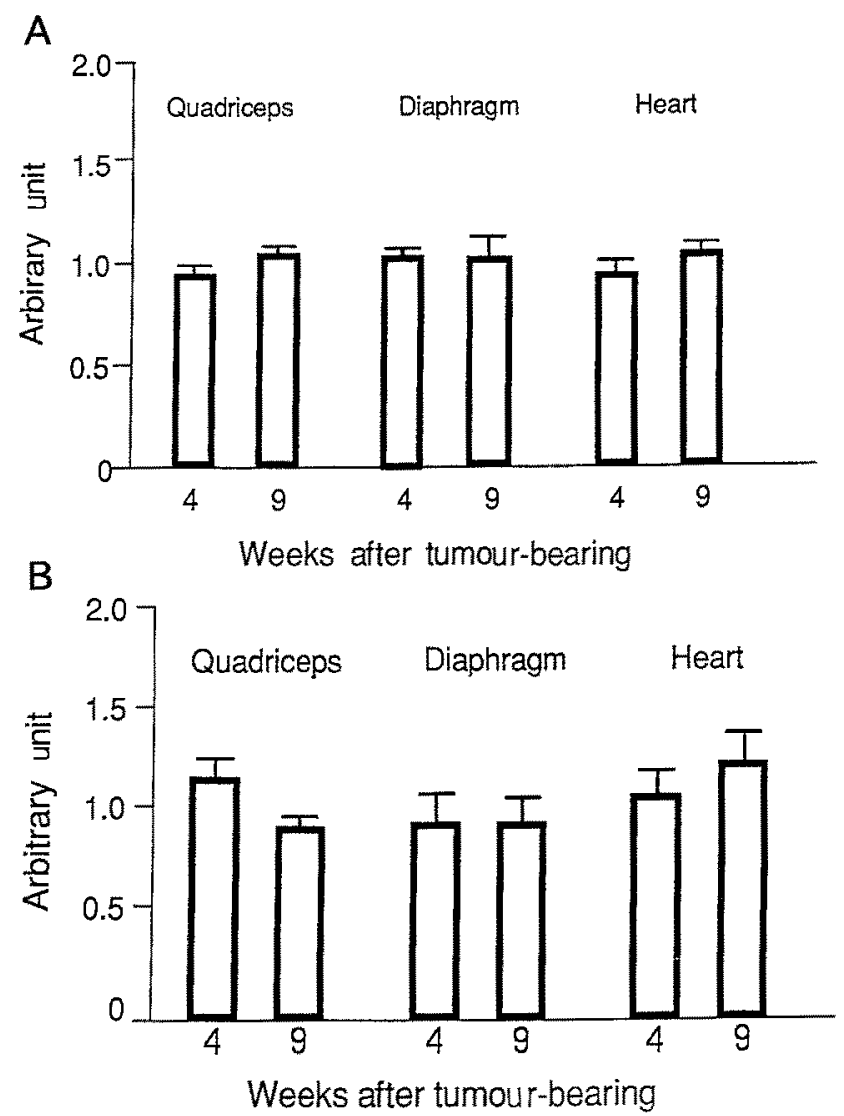

Fig. 4A, B. Quantitative analysis of the amount of GLUT proteins at 4 and 9 weeks in the different muscles. Arbitrary unit indicates the ratio of

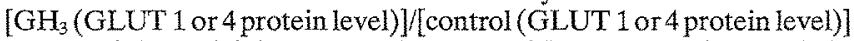
measured by a Bioimage Analyser. A: GLUT 1 protein, $n=3-8$; B: GLUT 4 protein, $n=4,5$. There were statistically significant differences between time points for GLUT expression in all of the muscles studied

bearing and respective control rats ( 4 and 9 weeks). The results of quantitative bioimage analysis are summarized in Figure 4. At 4 and 9 weeks after injecting tumour cells, the abundance of GLUT 1 and 4 protein in each muscle was not altered.

\section{Discussion}

The mechanisms responsible for the diabetogenic action of GH on insulin-sensitive tissues are poorly understood although $\mathrm{GH}$ has been reported to antagonize the effects of insulin on glucose metabolism. Our experimental data demonstrate that chronic $\mathrm{GH}$ elevation itself did not alter the expression levels of GLUT 1 and GLUT 4 in rat skeletal muscles. Despite the alteration of glucose uptake by GH reported in the cultured cells $[37,38]$, elevated circulating GH and IGF-I concentrations did not induce abnormalities in glucose regulation during in vivo experimental periods studied [39]. By 4 weeks serum GH concentrations were only doubled as compared to 9 weeks when $\mathrm{GH}$ concentrations were 40 - to 60 -fold greater than control rats. Even if the rats used in our study, as in the study of Bates et al. [40] were neither obese nor diabetic, there does not appear to be any altered expression of GLUT in 
skeletal muscles. Differential expression and regulation of GLUT 1 and 4 in different muscles have been reported $[41,42]$. In humans, there are no changes in GLUT 1 or GLUT 4 mRNA or protein levels in skeletal muscle from obese subjects or obese Type 2 diabetic (non-insulin-dependent) subjects compared to controls $[43,44]$. As spontaneous obese mice (ob/ob) have been a useful model to study the mechanism of insulin resistance and diabetes susceptibility [45], their GLUT gene expression has been studied. However, the marked defect in glucose utilization of ob/ob mice is not due to a decrease of GLUT 4 levels [46]. Even among obese diabetic subjects, it is not known whether the expression of GLUT 1 or GLUT 4 in skeletal muscles is altered [43, 44, 47]. Tai et al. [48] have reported, using cultured adipose cells, that GH decreases GLUT 1 protein and mRNA levels and that levels of GLUT 4 are not regulated by chronic GH treatment. The amount of adipose tissue from $\mathrm{GH}$ tumour bearing rats was too small to be able to allow analysis of GLUT gene expression. In contrast insulin stimulates both GLUT 1 and GLUT 4 mRNA in rat L6 skeletal muscle cells $[48,49]$. However, no change in GLUT 1 and GLUT 4 expression was demonstrated although the circulating insulin level was known to be significantly elevated in these tumour-bearing animals [50]. Furthermore the significance of developmental regulation of GLUT expression has been reported in various tissues [51]. Taken together with these observations, elevated insulin and IGF-I levels did not affect the expression of GLUT 1 and 4 genes in our in vivo models during the experimental periods, suggesting that the interaction among these hormones on GLUT gene expression counteract each other. Alternatively, insulin resistance in these rats may occur independently of the interaction between GH and GLUT gene expression. The change in insulin-regulatable GLUT 4 gene expression was not apparent probably, in part, because of the small changes of circulating insulin levels under these $\mathrm{GH}_{3}$ tumour-bearing conditions. Our preliminary results, furthermore, demonstrated that over 18 weeks the tumour-bearing rats induced the elevation of circulating glucose levels. Rats, 20 weeks after $\mathrm{GH}_{3}$ cell injection showed a decreased expression of GLUT gene. However, diabetic rats which have large $\mathrm{GH}$ producing tumours over a long period are not suitable for analysing effects on GLUT gene expression. This is due to the deteriorating general condition of the rat and other multifactorial influences: i. e. overproduction of various cytokines and secondary cachexia. Alternatively, hyperglycaemia itself induced by GH excess might interfere with muscle GLUT gene expression. The potential alterations in GLUT protein distribution or function could be involved in the mechanisms for the diabetogenic effects of GH in the same way as for insulin resistance in human Type 1 (insulin-dependent) diabetes [52]. Finally using these animal models the interaction of other diabetogenic factors and muscle GLUT gene regulation can be studied.

Acknowledgements. The authors are grateful to Dr. S.Okuno, Dr. Y. Maeda and Dr. M. Watanabe for their technical assistance and to Ms C. Ichinose and R. Honda for secretarial help. The authors are grateful to Dr. H. Yamasaki for the insulin RIA information. The rats used for this study were maintained by Dr. H.Satoh and Mr. N.Kubo, in the Laboratory Animal Center for Biomedical Research, Nagasaki University School of Medicine after obtaining permission for animal experimentation.

\section{References}

1. Melmed S (1990) Acromegaly. N Engl J Med 322:966-977

2. Davidson MB (1987) Effect of growth hormone on carbohydrate and lipid metabolism. Endocrine Rev 8: 115-131.

3. Sönksen PH, Greenwood FC, Ellis JP, Lowy C, Rutterford A, Nabarro JDM (1967) Changes of carbohydrate tolerance in acromegaly with progress of the disease and in response of treatment. J Clin Endocrinol Metab 27: 1418-1430

4. Beck P, Schalch DS, Parker ML (1965) Correlative studies of growth hormone and plasma insulin concentrations with metabolic abnormalities in acromegaly. J Lab Clin Med 66: 366-379

5. Jadresic A, Banks LM, Child DF, Diamant L, Doyle FH, Joplin GF (1982) The acromegaly syndrome. Relation between clinical features, growth hormone values and radiological characteristics of the pituitary tumovers. Q J Med 202: 189-204

6. Flier JS, Moses AC (1989) Diabetes in acromegaly and other endocrine disorders. In: DeGroot LJ, Besser GM, Cahill GF et al. (eds) Endocrinology, vol 2. WB Saunders Co., Philadelphia, pp 1389-1399

7. MacGorman LR, Rizza RA, Gerich JE (1981) Physiological concentrations of growth hormone exert insulin-like and insulin antagonistic effects on both hepatic and extrahepatic tissues in man. J Clin Endocrinol Metab 53:556-559

8. Daughaday WH, Kipnis DM (1966) The growth promoting and anti-insulin action of somatotropin. Rec Prog Horm Res 22: 49-93

9. Zahnd GR, Steinke J, Renold AE (1960) Early metabolic effects of human growth hormone. Proc Soc Exp Biol Med 105: 455-470

10. Vaitkus P, Sirek A, Norwich KH, Strek OV, Unger RH, Harris V (1984) Rapid changes in hepatic glucose output after a pulse of growth hormone in dogs. Am J Physiol 246: E14-E20

11. Rizza RA, Mandarino LJ, Gerich JE (1982) Effects of growth hormone on insulin action in man: mechanisms of insulin resistance, impaired suppression of glucose production, and impaired stimulation of glucose utilization. Diabetes 31:663-669

12. Martin JM, Gagliardino JJ (1967) Effect of growth hormone on the isolated pancreatic islets of rat in vitro. Nature $213: 630-631$

13. Muggeo M, Bar RS, Roth J (1977) Changes in affinity of insulin receptors following oral glucose in normal adults. J Clin Endocrinol Metab 44: 1206-1209

14. Bates RW, Garrison MM (1967) Quantitative study of the diabetogenic action of ACTH and growth hormone in partially pancreatectomized rats. Endocrinology 81:527-534

15. Hansen I, Tsalikian E, Beaufrere B, Gerich J, Haymond M, Rizza $R$ (1986) Insulin resistance in acromegaly; defect in both hepatic and extrahepatic insulin action. Am J Physiol 250: E269-E273

16. James DE, Brown R, Navarro J, Pilch PF (1988) Insulin-regulatable tissues express a unique insulin sensitive glucose transport protein. Nature 333: 183-185

17. Morgan HE, Cadenas E, Regern DM, Park CR (1961) Regulation of glucose uptake in muscle. 2, Rate limiting steps and effect. J Biol Chem 236:262-268

18. Bell G, Kayano T, Buse JB et al. (1990) Molecular biology of mammalian glucose transporters. Diabetes Care 13: 198-243

19. Fukumoto H, Seino S, Imura H, Seino Y, Bell GI (1998) Characterization and expression of human HepG2/erythrocyte glucosetransporter gene. Diabetes 37:657-661

20. Fukumoto H, Seino S, Imura H et al. (1988) Sequence, tissue distribution, and chromosomal localization of mRNA encoding a human glucose transporter-like protein. Proc Natl Acad Sci USA 85: $5434-5438$

21. Thorens B, Sarkar HK, Kaback HR, Lodish HF (1988) Cloning and functional expression in bacteria of a novel glucose transpor- 
ter present in liver, intestine, kidney, and $\beta$-pancreatic islet cells. Cell 55: 281-290

22. Orci L, Thorens B, Ravazzola M, Lodish HF (1989) Localization of the pancreatic beta cell glucose transporter to specific plasma membrane domains. Science 245: 295-297

23. Permutt MA, Koranyi L, Keller K, Lacy PE, Scharp DW, Mueckler M (1989) Cloning and functional expression of a human pancreatic islet glucose-transporter cDNA. Proc Natl Acad Sci USA 86: 8688-8692

24. Chen L, Alam T, Johnson JH, Hughes S, Newgard CB, Unger RH (1990) Regulation of $\beta$-cell glucose transporter gene expression. Proc Natl Acad Sci USA 87: 4088-4092

25. Johnson JH, Newgard CB, Milburn JL, Lodish HF, Thorens B (1990) The high $\mathbf{K}$ glucose transporter of islets of Langerhans is functionally similar to the low affinity transporter of liver and has an identical primary sequence. J Biol Chem 265: 6548-6551

26. Harakawa S, Yamashita S, Tobinaga T et al. (1990) In vivo regulation of hepatic insulin-like growth factor-I mRNA with thyroid hormone. Endocrinol Jpn 37:205-211

27. Tashjian AH (1979) Clonal strains of hormone-producing pituitary cells. Methods Enzymol 58:527-535

28. Yamashita S, Slanina S, Kado H, Melmed S (1986) Autoregulation of pituitary growth hormone messenger ribonucleic acid levels in rats bearing transplantable mammosomatotrophic pituitary tumours. Endocrinology 118:915-918

29. Chomcznski P, Sacchi N (1987) Single step method of RNA isolation by acid guanidinium thiocyanate-phenol chloroform extraction. Analyt Biochem 162: 156-159

30. Yamashita S, Melmed S (1986) Effects of insulin on rat anterior pituitary cells: inhibition of growth hormone secretion and mRNA levels. Diabetes 35: 440-447

31. Yamashita S, Tobinaga T, Ashizawa K et al. (1988) Glucose stimulation of protooncogene expression and deoxyribonucleic acid synthesis in rat islet cell line. Endocrinology 123: 1825-1829

32. Flier JS, Mueckler M, McCall AL, Lodish HF (1987) Distribution of glucose transporter messenger RNA transcripts in tissue of rat and man. J Clin Invest 79:657-661

33. James DE, Strube M, Mueckler M (1989) Molecular cloning and characterization of an insulin-regulatable glucose transporter. Nature 338: 83-87

34. Ponte P, Gunning P, Blau M, Kedes L (1983) Human actin genes are single copy for $\alpha$-skeletal and $\alpha$-cardiac actin but multicopy for $\beta$ and $\gamma$-cytoskeletal genes: $3^{\prime}$-untranslated regions are isotope specific but are conserved in evolution. Mol Cell Biol 3: $1783-1791$

35. Lin JL, Asano T, Shibasaki Y et al. (1991) Altered expression of glucose transporter isoforms with aging in rats - selective decrease in GLUT 4 in the fat tissue and skeletal muscle. Diabetologia 34: 477-482

36. Laemmli UK (1970) Cleavage of structural proteins during the assembly of the head of bacteriophage $T_{4}$. Nature 227:680-685

37. Takeda S, Podskalny I, Gorden P (1984) Direct effect of human growth hormone to inhibit glucose uptake in cultured human fibroblasts. Metabolism 33: 658-661

38. Silverman MS, Mynarcik DC, Corin RE, Haspel HC, Sonenberg M (1989) Antagonism by growth hormone of insulin-sensitive hexose transport in 3T3-F442A adipocytes. Endocrinology 125: 2600-2604

39. Davidson MB, Shen DC, Venkatesan $N$, Sladen G (1987) In vivo insulin antagonism but evanescent in vitro tissue effect in rats with growth hormone-secreting tumors. J Endocrinol Invest 10: $569-574$
40. Bates RW, Scow RO, Lacy PE (1966) Induction of permanent diabetes in rats by pituitary hormones from a transplantable mammotropic tumour. Concomitant changes in organ weight and the effects of adrenectomy. Endocrinology 78: 826-831

41. Kahn BB, Rossetti L, Lodish HF, Charron MJ (1991) Decreased in vivo glucose uptake but normal expression of GLUT 1 and GLUT 4 in skeletal muscle of diabetic rats. $J$ Clin Invest 87 : 2197-2206

42. Richardson JM, Balon TW, Treadway JL, Pessin JE (1991) Differential regulation of glucose transporter activity and expression in red and white skeletal muscle. J Biol Chem 266: 12690 12694

43. Pedersen O, Bak JF, Andersen PH et al. (1990) Evidence against altered expression of GLUT 1 or GLUT 4 in skeletal muscle of patients with obesity or NIDDM. Diabetes 39: 865-870

44. Handberg A, Vaag A, Damsbo P, Beck-Nielsen H, Vinten J (1990) Expression of insulin regulatable glucose transporter in skeletal muscle from type 2 (non-insulin-dependent) diabetic patients. Diabetologia 33: 625-627

45. Cuendet GS, Loten ER, Jeanrenaud B, Renold AE (1976) Decreased basal, noninsulin-stimulated glucose uptake and metabolism by skeletal soleus muscle isolated from obese-hyperglycemic (ob/ob) mice. J Clin Invest 58: 1078-1088

46. Koranyi L, James D, Mueckler M, Permutt MA (1990) Glucose transporter levels in spontaneously obese $(\mathrm{db} / \mathrm{db})$ insulin resistant mice. J Clin Invest 85: 962-967

47. Dohm GL, Elton CW, Friedman JE et al. (1991) Decreased expression of glucose transporter in muscle from insulin-resistant patients. Am J Physiol 260: E459-E463

48. Tai P-KK, Liao J.F, Chen EH, Dietz J, Schwartz J, Carter-Su C (1990) Differential regulation of two glucose transporters by chronic growth hormone treatment of cultured 3T3-F442A adipose cells. J Biol Chem 265: 21828-21834

49. Walker PS, Ramlal T, Donovan JA et al. (1989) Insulin and glucose-dependent regulation of the glucose transport system in the rat L6 skeletal muscle cell line. J Biol Chem 264: 6587-6595

50. Venkatesan N, Davidson MB (1990) Insulin-like growth factor I receptors in adult rat liver: characterization and in vivo regulation. Am J Physiol 258: E329-E337

51. Santalucia T, Camps M, Castello A et al. (1992) Developmental regulation of GLUT 1 (Eryhtrocyte/Hep G2) and GLUT 4 (muscle/Fat) glucose transporter expression in rat heart, skeletal, and brown adipose tissue. Endocrinology 130: 837-846

52. Kahn BB, Rosen AS, Bak JF et al. (1992) Expression of GLUT 1 and GLUT 4 glucose transporters in skeletal muscle of humans with insulin-dependent diabetes mellitus: regulatory effect of metabolic factors. J Clin Endocrinol Metab 74: 1101-1109

Received: 12 October 1992

and in revised form: 29 December 1992

Dr. S. Yamashita

Department of Cell Physiology

Atomic Disease Institute

Nagasaki University School of Medicine

1-12-4 Sakamoto

Nagasaki 852

Japan 